Persepsi Pemustaka Terhadap Desain Interior ... (Wiyarsih)

\title{
PERSEPSI PEMUSTAKA TERHADAP DESAIN INTERIOR DI PERPUSTAKAAN FAKULTAS MIPA UGM
}

\author{
Wiyarsih \\ Pustakawan Universitas Gadjah Mada \\ wiyarsih@ugm.ac.id
}

Penelitian ini merupakan penelitian deskriptif dengan pendekatan kuantitatif yang bertujuan untuk mengetahui persepsi pemustaka terhadap desain interior di Perpustakaan FMIPA UGM. Subjek penelitiannya adalah pemustaka dan obyeknya adalah desain interior di Perpustakaan FMIPA UGM. Metode pengumpulan data dalam penelitian ini adalah dengan observasi, dokumentasi, dan kuesioner. Analisis data yang digunakan adalah analisis kuantitatif. Berdasarkan hasil penelitian terhadap 10 (sepuluh) elemen desain interior ruang perpustakaan diketahui bahwa persepsi pemustaka terhadap 8 (delapan) elemen desain interior yaitu tata letak, variasi, hirarki, pencahayaan, tata suara, suhu udara, perawatan dan kualitas udara ruang perpustakaan, tergolong baik. Sedangkan persepsi pemustaka terhadap 2 (dua) elemen yang lain yaitu ruang personal dan gaya dan fashion tergolong cukup baik. Elemen gaya dan fashion mendapat nilai grand mean terendah yaitu 2,934. Sedangkan grand mean tertinggi pada elemen pencahayaan ruang perpustakaan yaitu 3,870.

Kata kunci: Persepsi; pemustaka; desain interior; ruang perpustakaan

\section{Pendahuluan}

\section{Latar Belakang}

Perpustakaan adalah sebuah ruangan, bagian sebuah gedung ataupun gedung itu sendiri yang digunakan untuk menyimpan buku dan terbitan lainnya menurut tata susunan tertentu untuk digunakan pembaca, bukan untuk dijual (SulistyaBasuki, 1993). Pendapat Sulistya-Basuki tersebut sampai saat ini masih relevan untuk diterapkan. Gedung atau ruang perpustakaan merupakan salah satu unsur penting dari suatu perpustakaan selain koleksi, SDM (sumber daya manusia), dan sarana prasarana. Walaupun saat ini sudah memasuki era digital, pemustaka masih tetap membutuhkan ruang di perpustakaan, bahkan kebutuhan ruang ini semakin meningkat seiring dengan semakin kompleksnya kebutuhan pemustaka.

Di era teknologi informasi ini pemustaka berkunjung ke perpustakaan tidak hanya untuk meminjam buku, tetapi juga melakukan berbagai aktivitas untuk menunjang pembelajaran. Pemustaka biasanya menggunakan ruang perpustakaan untuk belajar, membaca, akses internet, juga untuk berkolaborasi dengan teman seperti untuk berdiskusi, belajar kelompok, dan sebagainya. Untuk itulah perpustakaan harus menyediakan ruang beserta fasilitasnya.

Gedung perpustakaan sebagai suatu sistem terdiri dari beberapa ruang sebagai sub sistem yang harus tertata dengan baik sehingga dapat berfungsi sebagaimana mestinya. Masing-masing ruang mempunyai fungsi yang berbeda sesuai dengan kegiatan perpustakaan. Misalnya ruang koleksi, ruang referensi, ruang sirkulasi, ruang baca, ruang belajar, ruang diskusi, ruang pelatihan dan sebagainya. Selain tertata dengan baik, ruang tersebut harus nyaman dan aman agar pemustaka senang dan betah di perpustakaan.

Perpustakaan Fakultas MIPA UGM sebagai perpustakaan perguruan tinggi juga dituntut untuk menyediakan berbagai ruang sesuai kebutuhan pemustaka. Namun sampai saat ini Perpustakaan FMIPA UGM baru menyediakan beberapa ruang yang pokok yaitu ruang sirkulasi, ruang referensi, ruang pengolahan, dan ruang belajar bersama. Untuk ruang yang lainnya seperti ruang belajar 
mandiri, ruang diskusi, ruang pelatihan, ruang audio visual atau multimedia dan sebagainya belum tersedia karena keterbatasan tempat dan sarana prasarana.

Daya tampung ruang baca sesuai dengan jumlah kursi yang ada hanya 173 orang. Hal ini tidak sebanding dengan jumlah anggota Perpustakaan FMIPA yang berjumlah 1.973 orang sehingga banyak mahasiswa yang berada di sekitar perpustakaan atau di ruang belajar terbuka apabila perpustakaan sudah penuh pengunjung. Kondisi dan suasana di ruang perpustakaan juga belum nyaman, terutama pada waktu siang hari terasa panas apabila perpustakaan penuh pengunjung.

Berdasarkan kenyataan tersebut maka perlu ada evaluasi desain ruang perpustakaan agar pemustaka merasa aman, nyaman, efisien, efektif sehingga betah berada di perpustakaan. Untuk itu perlu diketahui bagaimana persepsi pemustaka terhadap desain interior ruang di Perpustakaan FMIPA UGM.

\section{Landasan Teori}

\section{Pengertian Persepsi}

Menurut Walgito (2004), persepsi merupakan pengorganisasian, penginterpretasian terhadap stimulus yang diinderanya sehingga merupakan sesuatu yang berarti, dan merupakan respon yang integrated dalam diri individu. Sedangkan menurut Siagian (1995), persepsi dapat dipahami sebagai suatu proses melalui mana seseorang mengorganisasikan dan menginterpretasikan kesan-kesan sensorinya dalam usahanya memberikan sesuatu makna tertentu kepada lingkungannya.

Menurut Walgito (1991), persepsi seseorang terhadap suatu objek dipengaruhi oleh faktor internal dan faktor eksternal. Faktor internal berupa apa yang ada dalam diri individu yang mempersepsi (segi kejasmanian dan psikologis), sedangkan faktor eksternal berupa stimulus dan lingkungan. Stimulus dan lingkungan sebagai faktor eksternal dan individu sebagai faktor internal saling berinteraksi dalam individu mengadakan persepsi

Siagian (1995) menyatakan bahwa faktorfaktor yang mempengaruhi persepsi adalah 1). Diri orang yang bersangkutan sendiri. Apabila seseorang melihat sesuatu dan berusaha memberikan interpretasi tentang apa yang dilihatnya itu, ia dipengaruhi oleh karakteristik individual yang turut berpengaruh seperti sikap, motif, kepentingan, minat, pengalaman dan harapannya. 2). Sasaran persepsi tersebut. Sasaran itu mungkin berupa orang, benda atau peristiwa. Sifat-sifat sasaran itu biasanya berpengaruh terhadap persepsi orang yang melihatnya. 3). Faktor situasi. Persepsi harus dilihat secara kontekstual yang berarti dalam situasi mana persepsi itu timbul perlu mendapat perhatian. Situasi merupakan faktor yang turut berperan dalam penumbuhan persepsi seseorang.

\section{Gedung atau Ruang Perpustakaan}

Perpustakaan adalah sebuah gedung atau ruangan di mana di dalamnya terjadi proses kegiatan pengumpulan, pengolahan, penyimpanan dan penyebarluasan bahan pustaka (informasi) untuk keperluan pemustaka Achmad dkk. (2012). Lebih lanjut dinyatakan bahwa karena semua kegiatan perpustakaan dilaksanakan di dalam gedung perpustakaan maka perancangan gedung perpustakaan harus disesuaikan dengan fungsi perpustakaan.

Lasa HS (2008) menyatakan bahwa bangunan maupun ruang untuk perpustakaan sebenarnya tidak sesederhana yang dibayangkan orang. Ditinjau dari segi bangunan, perpustakaan merupakan suatu organisasi yang memiliki sub-sub sistem yang memiliki fungsi berbeda-beda. Oleh karena itu, dalam perencanaan gedung dan ruang perpustakaan perlu memperhatikan fungsi tiap ruang, unsur-unsur keharmonisan dan keindahan, baik dari segi interior maupun eksterior. Ruang yang tertata baik akan memberikan kepuasan kepada pemakainya (pegawai perpustakaan dan pengguna 
perpustakaan). Lebih lanjut Lasa HS menyatakan bahwa keberadaan gedung maupun ruang perpustakaan dimaksudkan untuk menampung dan melindungi koleksi dari kerusakan, sekaligus sebagai wadah untuk melaksanakan kegiatan kepustakawanan.

\section{Kebutuhan Ruang}

Menurut Lasa HS (2008), setiap perpustakaan memiliki kebutuhan ruangan sendiri-sendiri berdasarkan pemakai, macam kegiatan, dan pemanfaatannya yang berbeda. Lebih lanjut dinyatakan bahwa pada dasarnya kebutuhan ruang perpustakaan dialokasikan untuk koleksi, pemakai, staf, dan keperluan lain. Kebutuhan ruang untuk perpustakaan perguruan tinggi lebih variatif.

Thompson (1974) dalam Lasa HS (2008), menyatakan perlunya dibedakan antara program diploma dan program pascasarjana. Disarankannya bahwa kebutuhan ruang perpustakaan untuk diploma dan sarjana adalah 1,223 $\mathrm{m}^{2} /$ mahasiswa dan untuk mahasiswa pascasarjana memerlukan ruang seluas 3,253 $\mathrm{m}^{2} /$ mahasiswa. Menurut Depdikbud (1994) dalam Lasa HS (2008), apabila perpustakaan itu menganut sistem tertutup, maka alokasinya adalah 45\% untuk koleksi, 25\% untuk pengguna, 20\% untuk staf, dan 10\% untuk keperluan lain. Apabila suatu perpustakaan menganut sistem terbuka, maka alokasinya diatur dengan pembagian $70 \%$ untuk koleksi dan pengguna, 20\% untuk staf, dan $10 \%$ untuk keperluan lain.

\section{Desain Interior Perpustakaan}

Arti desain interior menurut D.K. Ching (1995) dalam Sainttyauw (2013) adalah merencanakan, menata, dan merancang ruang-ruang interior dalam bangunan, yang berfungsi untuk memenuhi kebutuhan dasar akan sarana untuk bernaung dan berlindung, menentukan sekaligus mengatur aktivitas, memelihara aspirasi dan mengekspresikan ide, tindakan serta penampilan, perasaan, dan kepribadian.

Widjaja

(2009) dalam Achmad menyatakan bahwa arsitektural perpustakaan perlu dibenahi untuk menarik masyarakat yang memanfaatkan fasilitas tersebut. Bangunan perpustakaan selama ini masih terkesan konvensional sehingga sudah saatnya dirancang dengan memperhatikan unsur "fashionable dan fungsional".

Menurut Lasa HS (2008), produktivitas manusia yang bekerja di ruangan dipengaruhi oleh faktor pribadi (internal) dan faktor di luar dirinya (eksternal). Perasaan, emosi, motivasi, kesehatan, dan keyakinan seseorang mempengaruhi produktivitas mereka. Demikian pula lingkungan kerja sebagai faktor eksternal akan mempengaruhi produktivitas kerja. Lebih lanjut Lasa HS menyatakan bahwa dalam pencapaian kondisi lingkungan kerja itu dipengaruhi oleh beberapa faktor, seperti temperatur, sirkulasi udara, warna, pencahayaan, suara, dan tata letak.

Lasa HS (2008) menyatakan bahwa dalam perencanaan ruangan perlu dipertimbangkan bahwa keserasian dalam penataan ruang akan mempengaruhi produktivitas, efisiensi, efektifitas, dan kenyamanan pemakai. Untuk itu dalam penataan ruang baca, ruang koleksi, dan ruang sirkulasi dapat dipilih dari sistem tata sekat, tata parak, dan tata baur. 1) Sistem tata sekat yakni cara pengaturan ruangan perpustakaan yang menempatkan koleksi terpisah dari ruang baca pengunjung. Dalam sistem ini, pengunjung tidak diperkenankan masuk ke ruang koleksi dan petugaslah yang akan mengambilkan dan mengembalikan koleksi yang dipinjam atau dibaca di tempat itu. 2) Sistem tata parak, yakni suatu sistem pengaturan ruangan yang menempatkan koleksi terpisah dari ruang baca. Hanya saja dalam sistem ini, pembaca dimungkinkan untuk mengambil koleksi sendiri, lalu dicatat dan/atau dibaca di ruang lain yang tersedia. 3) Sistem tata baur, yakni suatu cara penempatan koleksi yang dicampur dengan ruang baca agar pembaca lebih mudah mengambil 
dan mengembalikan sendiri.

Kugler (2007) dalam Sainttyauwn (2013) menyatakan bahwa terdapat beberapa unsur yang membentuk desain interior diantaranya yaitu: tata ruang, variasi, hirarki, area personal, pencahayaan, tata suara, suhu udara, perawatan, kualitas udara, gaya dan fashion.

Penelitian tentang desain interior perpustakaan telah banyak dilakukan, antara lain oleh Susanti (2014), Ajie (2011), Sainttyauw (2013) dan Sentrani (2012). Susanti (2014) meneliti tentang Desain Interior Perpustakaan sebagai Sarana Edukasi dan Hiburan dengan Konsep Post Modern. Hasil penelitiannya bahwa dalam desain interior perpustakaan, perencanaan desain interior ruang dan pembentukan suasana ruang sangat penting agar dapat memberikan kenyamanan, atmosphere belajar yang menyenangkan dan dapat mempengaruhi psikologi pengguna sehingga minat bacanya meningkat.

Ajie (2011) meneliti tentang Pengaruh Desain Interior Perpustakaan terhadap Pembentukan Citra positif Perpustakaan. Hasil penelitiannya bahwa faktor fisik dan non fisik desain interior Perpustakaan UPI berpengaruh secara signifikan terhadap pembentukan citra positif Perpustakaan UPI. Total pengaruh variabel fisik interior sebesar $41,30 \%$ dan total pengaruh variabel non fisik sebesar $21,99 \%$.

Sainttyauw (2013) melakukan penelitian yang berjudul Pengaruh Desain Interior Perpustakaan terhadap Kenyamanan Pengguna di Perpustakaan Universitas 17 Agustus 1945 Surabaya. Hasil penelitian ini menyatakan bahwa ada pengaruh yang ditimbulkan oleh desain interior yang meliputi ruang, variasi, hirarki, area personal, pencahayaan, tata suara, suhu udara, perawatan, kualitas udara, gaya dan fashion terhadap kenyamanan pengguna di perpustakaan Universitas 17 Agustus 1945 Surabaya. Variabel yang paling dominan berpengaruh terhadap kenyamanan pengguna di perpustakaan Universitas 17 Agustus 1945 Surabaya adalah suhu udara dengan total mean skor sebesar 4.12 .

Sentrani (2012) melakukan penelitian yang berjudul Perancangan Interior Perpustakaan School of Design Universitas Bina Nusantara. Berdasarkan observasi ke beberapa perpustakaan universitas dan perpustakaan fakultas, hanya sedikit perpustakaan yang melalui perancangannya tercipta suasana nyaman bagi pengunjung perpustakaan. Konsep yang diterapkan dalam perancangan ini yaitu Young but Calm. Perpustakaan dirancang sesuai dengan karakteristik mahasiswa yang berjiwa muda dan agar tercipta suasana yang homey dan menenangkan, juga diperlukan treatment bentuk dan warna yang menenangkan.

Dalam penelitian ini, untuk mengukur persepsi pemustaka terhadap desain interior ruang di Perpustakaan FMIPA UGM akan menggunakan elemen-elemen desain interior dalam penelitian Sainttyauwn (2013) yang dimodifikasi sesuai kondisi di Perpustakaan FMIPA UGM yaitu meliputi variabel: ruang, variasi, hirarki, area personal, pencahayaan, tata suara, suhu udara, perawatan, kualitas udara, gaya dan fashion. Penelitian Sainttyauwn (2013) merupakan penelitian eksplanasi, sedangkan pada penelitian ini merupakan penelitian deskriptif.

\section{Metode Penelitian}

Penelitian ini merupakan penelitian deskriptif dengan pendekatan kuantitatif. Penelitian dilakukan di Perpustakaan Fakultas MIPA UGM selama 6 (enam) bulan mulai bulan Mei sampai Oktober 2016. Subjek penelitiannya adalah pemustaka di Perpustakaan Fakultas MIPA UGM. Sedangkan objeknya adalah desain interior di Perpustakaan FMIPA UGM. Variabelnya adalah desain interior di Perpustakaan Fakultas MIPA UGM.

Populasi dalam penelitian iniadalah pemustaka (mahasiswa) Fakultas MIPA UGM sebanyak 4.081 orang (data primer bulan April 2016 dari Bagian Akademik Fakultas MIPA UGM). Sedangkan sampelnya adalah pemustaka (mahasiswa) Fakultas 
MIPA UGM yang kebetulan bertemu dengan peneliti di perpustakaan. Berdasarkan rumus tersebut diperoleh jumlah sampel dalam penelitian ini adalah 97,6 dan dibulatkan menjadi 100.

Penelitian ini menggunakan instrumen angket/ kuesioner tertutup. Instrumen dikembangkan dari variabel desain interior perpustakaan yang kemudian dijabarkan ke dalam 10 sub variabel yaitu sub variabel tata ruang, variasi, hirarki, area personal, pencahayaan, tata suara, suhu udara, perawatan, kualitas udara, gaya dan fashion dan dari masingmasing sub variabel dijabarkan dalam beberapa indikator. Untuk penyekoran dan pengukuran pada alternatif jawaban, penelitian ini menggunakan skala Likert.

Pada penelitian ini instrumen yang diuji validitasnya adalah instrumen desain interior di Perpustakaan Fakultas MIPA UGM. Pengujian validitas dilakukan dengan menghitung korelasi antara masing-masing pertanyaan dengan skor total dengan menggunakan teknik korelasi product moment, yang dilakukan dengan bantuan komputer menggunakan program SPSS.

Metode pengumpulan data dengan metode observasi, dokumentasi, dan kuesioner. Penelitian ini menggunakan analisis deskriptif kuantitatif. Tahapannya adalah pengecekan identititas responden, pengecekan data, tabulasi data, pengolahan data, penafsiran hasil olah data, penarikan kesimpulan, kemudian memberikan rekomendasi hasil penelitian.

Berdasarkan rumus skala interval yang dikemukakan oleh Simamora (2004), maka nilai rerata jawaban pada setiap variabel dikelompokkan ke dalam 5 kategori penafsiran. yaitu sebagai berikut:

$$
\begin{aligned}
& 1,00-1,75 \text { sangat tidak baik } \\
& 1,76-2,50 \text { tidak baik } \\
& 2,51-3,25 \text { cukup baik } \\
& 3,26-4,50 \text { baik } \\
& 4,51-5,00 \text { sangat baik }
\end{aligned}
$$

\section{Pembahasan}

\section{Uji Validitas dan Reliabilitas Instrumen}

Berdasarkan hasil pengujian validitas variabel desain interior di Perpustakaan FMIPA UGM, maka 45 butir pertanyaan dinyatakan valid atau shahih karena korelasi antara skor butir pertanyaan dengan skor total $(r)$ dalam instrument lebih dari 0,3. Menurut Sugiono (1998), syarat minimum yang dianggap untuk memenuhi syarat/valid adalah apabila $r=0,3$.

Uji reliabilitas instrument dihitung dengan menggunakan koefisien Alpha. Menurut Sugiono (1998), apabila besarnya nilai $r$ antara 0,60-0,799 maka keandalannya termasuk kuat. Berdasarkan hasil pengujian reliabitas variabel desain interior di Perpustakaan Fakultas MIPA UGM, 45 butir pertanyaan dinyatakan realibel karena $r$ lebih dari 0,70 .

\section{Analisis Deskriptif Jawaban Responden}

\section{Persepsi Pemustaka terhadap Tata Letak Ruang Perpustakaan}

Persepsi pemustaka terhadap tata letak ruang Perpustakaan FMIPA UGM tergolong baik karena mendapat grand mean 3,528. Semua pernyataan mendapat nilai rerata antara 3,26 - 4,5. Rerata nilai tertinggi pada pernyataan bahwa pengaturan tata ruang dengan jarak yang tidak mengganggu aktivitas antar ruang, yaitu 3,81.

Pada pernyataan bahwa perbandingan luas antar ruang seimbang mendapat rerata nilai terendah yakni 3,30. Hal ini berarti masih perlu diperhatikan keseimbangan luas antar ruang. Persepsi pemusaka tergolong baik pada 2 (dua) pernyataan lainnya, yaitu bahwa pemisahan ruang sudah teratur sehingga tidak terkesan sempit dan bahwa jarak antar ruang tepat sehingga tidak menimbulkan kebisingan. Walaupun ruangan saling berdekatan, tetapi antar ruang disekat dengan tembok sehingga tidak mengganggu pemustaka di ruang yang lain. Pemustaka yang keluar masuk 
ruangan juga melalui pinggir ruangan sehingga tidak mengganggu konsentrasi pemustaka yang sedang belajar atau membaca.

\section{Persepsi Pemustaka terhadap Variasi Ruang Perpustakaan}

Persepsi pemustaka terhadap variasi ruang perpustakaan tergolong baik karena mendapat grand mean 3,533. Namun begitu, ada satu pernyataan yaitu pengaturan lampu di perpustakaan dapat membantu membedakan setiap ruangan mendapat rerata nilai terendah yaitu 3,19 yang berarti bahwa persepsi pemustaka terhadap pernyataan tersebut hanya cukup baik.

Untuk tiga dari empat pernyataan pada sub variabel tersebut rerata nilainya cukup tinggi walaupun belum maksimal. Perpustakaan FMIPA UGM sudah mempunyai berbagai jenis ruangan, tetapi perlu ditambah dengan ruangan yang lain sesuai kebutuhan pemustaka saat ini, misalnya ruang audiovisual/multimedia, ruang pelatihan, ruang belajar mandiri, ruang akses internet, dan sebagainya.

Rerata nilai tertinggi ada pada pernyataan pengaturan tempat duduk tidak menyebabkan sakit punggung dan atau leher. Tempat duduk dan meja di ruang baca perpustakaan sudah didesain sebagai sarana untuk membaca atau belajar di perpustakaan sehingga tidak membuat punggung dan atau leher sakit. Namun semua tempat duduk masih berfungsi sebagai tempat belajar serius, dan belum tersedia tempat duduk santai. Untuk itu perpustakaan perlu menambah variasi tempat duduk, misalnya karpet untuk lesehan, kursi sofa dan sebagainya agar pemustaka lebih nyaman belajar di perpustakaan.

\section{Persepsi Pemustaka terhadap Hirarki Ruang} Perpustakaan

Persepsi pemustaka terhadap hierarki ruang perpustakaan sudah termasuk baik kecuali pada pernyataan "Terdapat pintu darurat di dalam perpustakaan" dengan rerata nilai hanya 3,00 yang berarti masih tergolong cukup baik. Dari penilaian responden tersebut maka waktu mendatang perlu ada pintu darurat bagi pemustaka namun perlu diperhatikan faktor keamanannya.

Pernyataan bahwa penempatan ruang yang ada di perpustakaan mudah dijangkau oleh pengguna mendapat rerata nilai tertinggi di antara pernyataan yang lainnya pada sub variabel tersebut, yakni 3,99. Hal ini berarti bahwa persepsi pemustaka terhadap pernyataan tersebut tergolong baik. Hal ini karena ruang-ruang yang ada di perpustakaan saling berdekatan sehingga mudah dijangkau oleh pemustaka.

Persepsi pemustaka terhadap pernyataan yang lainnya juga baik. Di perpustakaan terdapat pembatas tembok atau sekat antara ruang yang satu dengan yang lainnya. Alur posisi ruangan di perpustakaanjugadapat dimengertioleh pengguna. Pemustaka masuk ruangan perpustakaan langsung dapat mengetahui dan melihat alur posisi ruangan, yaitu melalui pinggir ruangan.

Lantai, dinding, furnitur, ukuran, dan penempatan ruangan dapat dijadikan sebagai penanda pada setiap ruang. Penanda (signage) yang ada di perpustakaan juga dapat dijadikan sebagai penunjuk arah menuju tempat yang akan dituju. Hal ini karena setiap ruang diberi nama.

\section{Persepsi Pemustaka terhadap Area Personal Perpustakaan}

Persepsi pemustaka terhadap area personal perpustakaan hanya tergolong cukup baik kecuali pada pernyataan "Ruang personal hanya bisa digunakan untuk perorangan", termasuk kategori baik walaupun dalam batas minimal. Pernyataan bahwa ruang personal tidak tercampur dengan ruangan lain di dalam perpustakaan mendapat rerata nilai terendah yaitu 2,93. Ruang personal memang campur dengan ruang koleksi dan area layanan lain. Sebaiknya ruang personal dibuat tersendiri, tidak campur dengan ruangan lainnya 
sehingga tidak mengganggu konsentrasi belajar pemustaka. Selain itu privasi pemustaka juga lebih terjaga.

Pernyataan bahwa terdapat tempat yang dapat digunakan secara personal maupun kelompok, rerata nilainya hanya 3,16. Area personal terdapat di ruang referensi yang biasanya digunakan untuk membaca dan belajar. Namun karena ruangan ini belum betul-betul personal, sehingga kadangkadang juga digunakan untuk kegiatan kelompok. Sedangkan area untuk kelompok disediakan di ruang tersendiri. Di area itu mahasiswa dapat bebas beraktivitas, baik untuk kerja kelompok dan diskusi.

Di perpustakaan juga terdapat sekat atau batasan antara area untuk personal dan kelompok, namun hanya mendapat rerata nilai 3,03. Batasan itu berupa tembok, tetapi karena pintu dan jendela di area personal selalu terbuka sehingga apabila area kelompok ramai dapat mengganggu area personal. Hal ini berkaitan dengan kondisi perpustakaan yang masih menggunakan pintu dan jendela untuk sirkulasi udara secara alami. Sebaiknya ruang untuk personal maupun kelompok tertutup rapat tetapi menggunakan AC sehingga tidak mengganggu ruang lainnya.

Pernyataan bahwa ruang personal hanya bisa digunakan untuk perorangan mendapat rerata nilai tertinggi dibandingkan pernyataan yang lain walaupun dalam batas minimal, yaitu 3,27. Ruangan ini sebenarnya juga bisa untuk kelompok tetapi sudah terkondisi sebagai area belajar dan membaca secara personal. Untuk itu sebaiknya perpustakaan menyediakan ruangan khusus untuk personal.

\section{Persepsi Pemustaka terhadap Pencahayaan Ruang Perpustakaan}

Persepsi pemustaka terhadap semua pernyataan pada sub variabel tersebut tergolong baik. Cahaya di ruang perpustakaan merata, sampai pojok-pojok ruangan. Sebagian besar lampu juga tidak terhalang oleh benda-benda lain.
Kuat lemahnya cahaya (lampu) sehingga ruang terkesan terang (tidak panas). Hal ini juga dibantu dengan cahaya alam dari luar. Setiap hari semua jendela di ruang perpustakaan selalu dibuka sehingga dapat menambah terang ruangan. Perbandingan pengaturan cahaya lampu dengan cahaya alam juga sesuai. Warna cahaya di dalam ruangan dan di luar ruangan hampir sama sehingga tidak menimbulkan kontras. Warna cahaya lampu juga tidak membuat mata sakit.

Dengan penilaian yang baik dari responden terhadap pencahayaan maka perlu terus dipertahankan bahkan ditingkatkan. Apabila ada lampu yang rusak atau mati harus segera diganti agar tidak mengganggu kenyamanan pemustaka.

\section{Persepsi Pemustaka terhadap Tata Suara di Ruang Perpustakaan}

Persepsi pemustaka terhadap semua pernyataan pada sub variabel tata suara di ruang perpustakaan tergolong baik. Rerata terendah pada pernyataan bahwa pengaturan suara musik tidak mengganggu konsentrasi, yaitu 3,32. Musik dihidupkan di akhir layanan sebagai tanda kalau waktu layanan akan segera berakhir, sehingga tidak begitu mengganggu pemustaka.

Tata suara yang baik perlu dukungan sarana yang memadai seperti sound system dan ruang multimedia. Untuk itu perlu ada sarana tersebut sehingga dapat mendukung layanan kepada pemustaka.

\section{Persepsi Pemustaka terhadap Suhu Udara di Ruang Perpustakaan}

Persepsi pemustaka terhadap semua pernyataan pada sub variabel suhu udara di ruang perpustakaan tergolong baik. Di dalam ruangan perpustakaan terdapat ventilasi udara. Setiap ruang ada jendela yang langsung berhubungan dengan udara luar sehingga sirkulasi udara lancar. Di dalam ruangan perpustakaan juga terdapat pendingin 
ruangan berupa kipas angin jenis baling-baling. Kipas angin selalu dihidupkan sehingga dapat mengurangi udara yang panas. Pemasangan kipas angin juga tidak mengganggu kegiatan yang dilakukan di dalam perpustakaan. Hal ini karena kipas angin dipasang di langit-langit atap sehingga udara dapat menyebar ke seluruh ruangan.

Untuk pernyataan bahwa suhu udara dalam ruangan tidak menyebabkan kedinginan maupun kepanasan mendapat rerata nilai terendah. Hal ini karena perpustakaan hanya memakai kipas angin sehingga relatif sulit untuk mengatur suhu udara. Untuk itu sebaiknya dipasang air conditioning (AC) sehingga suhu dapat diatur sesuai dengan yang dikehendaki.

\section{Persepsi Pemustaka terhadap Perawatan Ruang Perpustakaan}

Persepsi pemustaka terhadap seluruh pernyataan pada sub variabel perawatan ruang perpustakaan tergolong baik. Lantai perpustakaan selalu dalam keadaan bersih. Kondisi ini perlu dipertahankan agar kondisi ruangan selalu bersih. Walaupun sudah ada petugas cleaning service, petugas perpustakaan hendaknya juga memperhatikan kebersihan ruangan.

Kondisi cat, dinding, lantai, dan pintu serta jendela di ruangan perpustakaan dalam kondisi baik. Cat ruangan perpustakaan tidak pudar, tidak mengelupas, dan bersih. Hal ini karena secara berkala diadakan pengecatan kembali semua gedung termasuk perpustakaan oleh Fakultas. Dinding ruangan perpustakaan tidak retak dan tidak lembab. Gedung perpustakaan termasuk bangunan lama di mana dinding ruang sangat kuat. Lantai di perpustakaan juga tidak pecah, tidak licin, permukaan lantai tidak menonjol. Pintu dan jendela di ruangan perpusakaan juga tidak rusak. Hampir semua pintu dan jendela di ruang perpustakaan terbuat dari kayu jati sehingga awet.

Pernyataan bahwa kaca-kaca (jendela, dinding, pintu) yang ada di perpustakaan selalu dibersihkan mendapat rerata nilai terendah dibandingkan pernyataan yang lain. Hal ini karena cleaning service jarang membersihkan kaca-kaca di jendela. Untuk itu petugas perpustakaan juga harus ikut peduli terhadap kebersihan kaca-kaca.

\section{Persepsi Pemustaka terhadap Kualitas Udara di Ruang Perpustakaan}

Persepsi pemustaka terhadap semua pernyataan pada sub variabel kualitas udara di ruang perpustakaan tergolong baik. Rerata tetinggi pada pernyataan tentang kebersihan udara dalam ruangan. Ruang perpustakaan cukup jauh dari jalan raya sehingga terhindar dari debu. Di sekeliling ruangan juga ada banyak tanaman yang dapat menyaring debu masuk ke ruang perpustakaan. Selain itu juga berkaitan dengan kondisi ruangan yang bersih sehingga udaranya juga bersih.

Pernyataan kesegaran udara dalam ruangan mendapat rerata nilai terendah. Hal ini karena perpustakaan dekat dengan kantin sehingga bau masakan selalu masuk ke dalam ruangan perpustakaan. Untuk pernyataan bahwa udara dalam ruangan sejuk (tidak pengap) juga tergolong baik. Hal ini karena perpustakaan berada pada lantai 1, terdapat sirkulasi udara yang lancar, serta banyak tanaman disekitar ruangan. Selain itu juga ada kipas angin dan jendela yang cukup di setiap ruang.

\section{Persepsi Pemustaka terhadap Gaya dan Fashion Ruang Perpustakaan}

Persepsi pemustaka terhadap hampir semua pernyataan pada sub variabel gaya dan fashion ruang perpustakaan hanya tergolong cukup baik kecuali pada pernyataan bahwa desain ruang perpustakaan memiliki nilai estetika (keindahan) tergolong baik walaupun dalam batas minimal. Perpustakaan FMIPA merupakan bangunan lama yang didesain menjadi ruang perpustakaan sehingga sulit untuk mengikuti gaya dan fashion 
Persepsi Pemustaka Terhadap Desain Interior ... (Wiyarsih)

masa kini. Dengan desain yang terkesan klasik sehingga kurang sesuai dengan jiwa mahasiswa yang cenderung bergaya modern. Untuk itu di perpustakaan perlu ada tambahan desain interior yang bergaya muda, seperti adanya sofa, karpet, ruang multimedia dan sebagainya.

Berdasarkan hasil penelitian terhadap seluruh sub variabel, grand mean tertinggi terdapat pada sub variabel Persepsi Pemustaka terhadap Pencahayaan Ruang Perpustakaan, yaitu 3,87. Grand mean yang hampir sama terdapat pada variabel Persepsi Pemustaka terhadap Suhu Udara Ruang Perpustakaan yaitu 3,86. Hal ini menunjukkan bahwa persepsi pemustaka tergolong baik terhadap kedua variabel tersebut.

Grand mean terendah terdapat pada sub variabel Persepsi Pemustaka terhadap Gaya dan Fashion Ruang Perpustakaan, yaitu 2,934. Perpustakaan FMIPA UGM merupakan bangunan yang sudah lama atau tua. Semua furnitur baik rak, meja, kursi, balkon terbuat dari kayu jati. Warna cat temboknya juga kalem, putih tulang atau krem dan lantainya masih tegel. Semua itu membuat kesan yang kuno dan klasik. Hal ini berbeda dengan selera mahasiswa yang selalu ingin mengikuti gaya masa kini, suasana yang ceria, dan warna yang cerah. Untuk itu perpustakaan perlu merubah penampilan mengikuti selera mahasiswa agar mempunyai daya tarik.

Sub variabel yang perlu diperhatikan juga adalah Persepsi Pemustaka terhadap Area Personal Ruang Perpustakaan karena mendapat grand mean minimal yaitu hanya 3,09. Hal ini karena perpustakaan belum mempunyai ruang yang benar-benar personal. Ruang personal sangat penting bagi pemustaka yang akan belajar mandiri dengan konsentrasi yang tinggi sehingga tidak terganggu oleh suasana luar.

Kebutuhan Mahasiswa terhadap Ruang dan Fasilitas Perpustakaan

\section{Kebutuhan Ruang}

Kebutuhan ruang yang paling banyak dibutuhkan pemustaka berturut-turut adalah ruang personal, ruang diskusi, ruang baca santai yang nyaman, dan ruang/lab komputer/internet dan ruang multimedia. Hal ini menunjukkan bahwa pemustaka di perpustakaan mempunyai kebutuhan ruang yang berbeda-beda sesuai dengan kegiatannya. Pemustaka saat ini selain membutuhkan ruang untuk belajar atau membaca juga membutuhkan ruang untuk berekspresi dan berinovasi.

\section{Fasilitas Ruang}

Pemustaka membutuhkan beberapa fasilitas ruang di Perpustakaan FMIPA yang belum ada misalnya LCD, layar LCD, $A C$, printer, scan, kursi sofa, kursi meja besar/bundar untuk diskusi, karpet, papan tulis, dan sebagainya. Untuk memenuhi kebutuhan pemustaka maka fasilitas tersebut perlu diadakan sesuai dengan fungsi ruangannya.

\section{Kesimpulan dan Saran}

Berdasarkan hasil penelitian tentang persepsi pemustaka terhadap desain interior di Perpustakaan Fakultas MIPA UGM, maka dapat disimpulkan sebagai berikut:

1. Persepsi pemustaka terhadap terhadap 10 elemen desain interior, 8 (delapan) elemen desain interior perpustakaan yaitu tata letak, variasi, hirarki, pencahayaan, tata suara, suhu udara, perawatan dan kualitas udara ruang perpustakaan tergolong baik, sedangkan terhadap 2 (dua) elemen lainnya yaitu terhadap area personal dan gaya dan fashion ruang perpustakaan tergolong cukup baik.

2. Elemen gaya dan fashion mendapat nilai grand mean terendah yaitu 2,934. Grand mean tertinggi pada elemen pencahayaan ruang perpustakaan yaitu 3,87.

Berdasarkan hasil penelitian, maka saran yang 
dapat disampaikan adalah:

1. Perpustakaan hendaknya mengubah gaya dan fashion ruang perpustakaan sesuai selera mahasiswa. Perpustakaan hendaknya juga mempunyai icon/simbol yang membedakan dengan perpustakaan lain. Dua hal itu akan menjadi daya tarik tersendiri bagi pemustaka sehingga diharapkan dapat meningkatkan minat pemustaka berkunjung ke perpustakaan.

2. Di dalam ruang perpustakaan hendaknya ada pintu darurat bagi pemustaka karena apabila terjadi suatu keadaan darurat dapat segera keluar dari ruang perpustakaan.

3. Bagi pengambil kebijakan hendaknya menambah ruang dan fasilitas yang belum tersedia di perpustakaan yang sesuai dengan kebutuhan pemustaka.

\section{Daftar Pustaka}

Achmad; Sutedjo, Mansur; Surono; dan Suprayitno, Edy. 2012. Layanan cinta: Perwujudan layanan prima ++ perpustakaan. Jakarta: Sagung Seto

Ajie, Miyarso Dwi. 2011. Pengaruh Desain Interior Perpustakaan terhadap Pembentukan Citra Positif Perpustakaan. Ejournal.upi.edu/index. php/edulib/article/.../792-. Diakses 11 April 2016

Lasa HS. 2008. Manajemen Perpustakaan. Yogyakarta: Gama Media

Sainttyauw, Adrina Ayu Candra Zelzi Jeint. 2013. Pengaruh Desain Interior Perpustakaan terhadap Kenyamanan Pengguna di Perpustakaan Universitas 17 Agustus 1945 Surabaya. http://journal.unair.ac.id/filerPDF/ Jurnal Adrina.pdf. Diakses 12 April 2016

Sentrani, Siane; Wulandari, Anak Agung Ayu.; Latif, Fauzia. 2012. Perancangan Interior Perpustakaan School of design Universitas Bina Nusantara. http://eprints.binus.ac.id/24669/1/2
011-2-00960-DI\%20Abstrak001.pdf. Diakses 12 April 2016

Siagian, Sondang P. 1995. Teori Motivasi dan Aplikasinya. Jakarta: Rineka Cipta.

Sulistyo-Basuki. 1993. Pengantar Ilmu Perpustakaan. Jakarta : Gramedia Pustaka Utama.

Susanti, Eka dan Budiono. 2014. "Desain Interior Perpustakaan sebagai Sarana Edukasi dan hiburan dengan Konsep Post Modern". Dalam http://id.portalgaruda. org/index.php?ref=browse\&mod=view article\&article $=149247$ Diakses 11 April 2016

Walgito, Bimo. 2004. Pengantar Psikologi Umum. Yogyakarta: Andi.

Walgito, Bimo. 1991. Psikologi Sosial: Suatu Pengantar. Yogyakarta: Andi. 